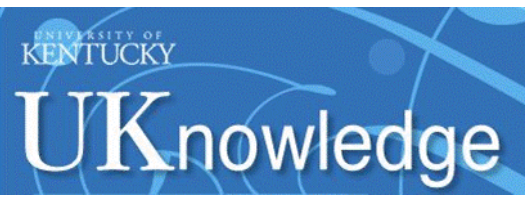

University of Kentucky

UKnowledge

7-2001

\title{
Young Geniuses and Old Masters: The Life Cycles of Great Artists from Masaccio to Jasper Johns
}

\author{
David W. Galenson \\ University of Chicago \\ Robert Jensen \\ University of Kentucky, robert.jensen@uky.edu
}

Follow this and additional works at: https://uknowledge.uky.edu/art_papers

Part of the Art and Design Commons

Right click to open a feedback form in a new tab to let us know how this document benefits you.

\section{Repository Citation}

Galenson, David W. and Jensen, Robert, "Young Geniuses and Old Masters: The Life Cycles of Great Artists from Masaccio to Jasper Johns" (2001). Art and Visual Studies Faculty Working Papers. 1. https://uknowledge.uky.edu/art_papers/1

This Working Paper is brought to you for free and open access by the Art and Visual Studies at UKnowledge. It has been accepted for inclusion in Art and Visual Studies Faculty Working Papers by an authorized administrator of UKnowledge. For more information, please contact UKnowledge@lsv.uky.edu. 


\title{
NBER WORKING PAPER SERIES
}

YOUNG GENIUSES AND OLD MASTERS:

THE LIFE CYCLES OF GREAT ARTISTS FROM MASACCIO TO JASPER JOHNS

\author{
David W. Galenson \\ Robert Jensen \\ Working Paper 8368 \\ http://www.nber.org/papers/w8368 \\ NATIONAL BUREAU OF ECONOMIC RESEARCH \\ 1050 Massachusetts Avenue \\ Cambridge, MA 02138 \\ July 2001
}

The views expressed herein are those of the authors and not necessarily those of the National Bureau of Economic Research.

(C) 2001 by David W. Galenson and Robert Jensen. All rights reserved. Short sections of text, not to exceed two paragraphs, may be quoted without explicit permission provided that full credit, including $(\subset$ notice, is given to the source. 
Young Geniuses and Old Masters:

The Life Cycles of Great Artists from Masaccio to Jasper Johns

David W. Galenson and Robert Jensen

NBER Working Paper No. 8368

July 2001

\begin{abstract}
$\underline{\text { ABSTRACT }}$
There have been two very different life cycles for great artists: some have made their greatest contributions very early in their careers, whereas others have produced their best work late in their lives. These two patterns have been associated with different working methods, as art's young geniuses have worked deductively to make conceptual innovations, while its old masters have worked inductively, to innovate experimentally. We demonstrate the value of this typology by considering the careers of four great conceptual innovators - Masaccio, Raphael, Picasso, and Johns - and five great experimental innovators - Michelangelo, Titian, Rembrandt, Cézanne, and Pollock. Recognition of the effect of an artist's methods on the timing of his contribution appears to solve a puzzle that has been recognized by art historians for more than a century.
\end{abstract}

David W. Galenson

Department of Economics

University of Chicago

1126 E. $59^{\text {th }}$ Street

Chicago, IL 60637

and NBER

sogrodow@midway.uchicago.edu
Robert Jensen

Department of Art

University of Kentucky 208A Fine Arts Building

Lexington, KY 40506

rjens1@pop.uky.edu 


\section{The Productivity of Painters}

Artists occupy a distinctive place in our economic life. As the art historian Meyer Schapiro observed, the works they produce are "perhaps the most costly man-made objects in the world." Supporting evidence abounds. Thus in the twelve months ending in July 2000, worldwide auction sales of works by Pablo Picasso totaled $\$ 232$ million; this raised total auction sales of Picasso's work since 1988 to $\$ 1.5$ billion. $^{2}$ And impressive as these numbers are, they vastly understate the wealth created by Picasso, for his most important works have long since been captured by museums, where they attract millions of viewers annually. ${ }^{3}$ It is not possible to estimate with any precision the market value of such landmark works as Les Demoiselles d'Avignon, the single most famous work owned by New York's Museum of Modern Art, or Madrid's Guernica, or the Picasso Museum's Still Life with Chair Caning. ${ }^{4}$ And although Picasso stands at the head of the line of modern painters, even among moderns he is hardly alone in having created work of enormous value, and it is likely that the wealth embodied in his work is modest compared to that of a number of old masters.

Curiously, economists have shown little interest in the extraordinary productivity of these workers: economists have devoted little attention to the determination of the market value of works of art, and even less to the process by which artists produce this value. ${ }^{5}$ The idea of making inexpensive materials the source of great wealth has long been a focus of popular interest, from the failed attempts of medieval alchemists to the sometimes successful efforts of contemporary internet entrepreneurs, but for whatever reason modern economists have displayed little curiosity about how artists have turned simple canvas and paint into objects of great worth.

Artists themselves have occasionally offered answers to this question. A notable instance 
occurred in 1878, when in the course of a libel suit he had brought against a critic, James McNeill Whistler was asked to justify the price of his work. When questioned by opposing counsel as to whether he really charged the purchaser of a painting the considerable sum of 200 guineas for the labor of just two days, Whistler replied "No, I ask it for the knowledge of a lifetime." " In 1884, Vincent van Gogh suggested a different explanation, when he wrote to a fellow painter of his belief that "art is something greater and higher than our own adroitness or accomplishments or knowledge; ... art is something which, although produced by human hands, is not created by these hands alone, but something which wells up from a deeper source in our souls."

Whether the value of great art stems from the accumulation of human capital, from divine intervention, or from some other source remains to be seen. Our work is intended as a step toward a systematic understanding of how some artists have created work of enormous value. Ours will doubtless not be the last word, for scientific study of this problem remains at an early stage, and as many art scholars are quick to insist, art history is a vastly complicated subject, full of idiosyncrasies and dark corners. Yet we believe that systematic comparative study of artists' methods and careers, an approach rarely used by art historians, can yield simple but powerful generalizations that can in fact explain many of these apparent idiosyncrasies and illuminate many of the previously dark corners.

\section{$\underline{\text { Artists and Age }}$}

Scholars of art have long been aware that most artists' work changes considerably over the course of their careers, and the literature of art history is replete with judgments of how the quality of artists' work has varied with age. Unfortunately, however, attempts at generalization 
have been rare: nearly all these judgments have been made about individual artists, and few scholars have even raised the question of whether there are typical life cycles for painters.

The most significant exception to this is probably art historians' attempts to describe what they have called artists" "Altersstil," or old-age style. The invention of the retrospective exhibition in the late $19^{\text {th }}$ century prompted some art scholars to conjecture about artists' life cycles, and the most lasting consequence of this has been the hypothesis that some artists have shared certain stylistic characteristics in old age. ${ }^{8}$ Over the course of the past century, however, research on the relationship between age and artistic style has been desultory, and the results unimpressive. So for example art historian David Rosand, the organizer of a 1985 symposium titled "Old-Age Style," could observe that "While apparently a commonplace in art-historical thought, old-age style is hardly a concept that has been subjected to sustained serious examination, nor is it a phenomenon that has been adequately defined." 9

Even the meager research efforts art historians have devoted to old-age style appear to have been misguided. In part this is because attempts to identify the concept have been restricted to a small number of arbitrarily chosen artists. ${ }^{10}$ And a basic problem has been the assumption that aging artists should share some specific stylistic characteristics. This extremely restrictive assumption has virtually guaranteed that any attempt at generalization across artists separated widely in time and space would make little progress. ${ }^{11}$

We believe that age - or more precisely experience - has had powerful common effects on artists' work, but that these effects have not involved stylistic similarities. We furthermore believe that there have been two very different life cycles for artists. These patterns appear to be related systematically both to the processes artists use in making their work and to artists' 
conceptions of the goals of their work. In this paper we will present a general hypothesis of artists' life cycles, and illustrate its application to the careers of some of the most celebrated painters in western history.

Before we can do this, however, it is necessary to consider the source of importance in art. This is because importance is the central criterion both for selecting artists to study - who are the most important artists? - and for assessing the impact of age on their work - what is an artist's most important work? Yet although defining importance in art might seem a daunting task, with any definition subject to nearly endless debate, this is actually not the case. The definition can in fact be provided quite readily, because there is a very broad consensus on this issue that has long been implicit in the critical literature of art history.

$\underline{\text { Importance in Art }}$

Many misunderstandings of the history of art, by art scholars as well as those outside the discipline, result from a failure to recognize some key parallels between art and other intellectual activities. One basic similarity concerns importance. The source of importance for artists is no more nebulous or complex than for scholars: as in academic disciplines, the principal source of genuine importance in art is innovation. Important artists are innovators whose work changes the practices of their successors; important works of art are those which embody these innovations. Although many art historians object to what they fear to be the demythicizing effect of this simple formulation, some scholars have been willing to express these ideas directly. So for example in discussing the parallel in this respect between art and science, Meyer Schapiro observed that a great artist is "a revolutionary spirit who remakes his art, disclosing ever new forms." ${ }^{12}$ Art historian George Kubler similarly compared art to science: "Every important work 
of art can be regarded both as a historical event and as a hard-won solution to some problem." 13

Some scholars would reject this characterization of artists as problem-solvers: in their view science progresses, with new solutions surpassing old ones, but art does not, since new art does not supersede old art. ${ }^{14}$ Yet as Arthur Koestler explained, this involves a misunderstanding of the evolution of art. Artists do solve problems, and their successors can use their discoveries without having to make them again. A valid distinction lies in the fact that unlike scientists, artists are free to choose whether to accept or reject the discoveries of their predecessors. But this does not change the fact that the earlier discoveries are available to them and consequently that "the achievements of art are indeed cumulative and irreversible, as those of science are."15

Histories of art, like intellectual histories of academic disciplines, are properly concerned with identifying the most important artistic discoveries and tracing their impact on other artists. The procession of great artists is not the artificial or arbitrary construct of scholars, but the product of artists, whose work reveals which artists of their own, or earlier, generations have been most influential. The most important element in any historian's account is therefore not the historian's judgment of the artist's work on aesthetic or other grounds, but rather the historian's ability to discern the artist's influence on other artists, and to explain the causes and consequences of that influence. Populist protests notwithstanding, art history must be first a history of a canon of central figures of great artists, for their discoveries are the prime subject of the narrative of art history, and the relationships among those discoveries are the source of the coherence of that narrative. Just as artists must study the history of art in order to make their predecessors' innovations available to them, we must study the great artists of the past to be able to understand the uses later artists make of their innovations. Great artists therefore dominate the 
scholarship of art history for the same reason they dominate the collections of great museums. So Sir Alan Bowness, former director of the Tate Gallery, defines the purpose of the museum through reference to these "artists of genius," declaring that "the museum collection aspires to show a chronological sequence of the work of such artists, carrying forward an argument which forms the material of any history of modern art." 16

Yet although great artists must be the central focus of art history, in understanding their achievements it is important not to ignore another parallel between art and science. For contrary to the popular - and sometimes scholarly - view of great artists as isolated geniuses, artistic progress has been overwhelmingly a product of collective research and collaboration. Like scholars, artists learn from teachers, and they develop their craft together with others of their own generation. Great artists have been disproportionately likely to have worked with teachers who were themselves important artists, and to have spent the formative stages of their careers in collaborative relationships with other important artists their own age. Some great artists, like Monet and Picasso, arrived at their greatest discoveries while working closely with peers, but even in cases in which great artists produced their major work in isolation, these were often, as for Cézanne and van Gogh, the consequences of working out the implications of trains of research that had originated in earlier apprenticeships and collaborations.

\section{A Typology of Artistic Innovators}

The recognition that innovation is the principal source of artistic importance allows us to approach the issue of artists' life cycles from a new point of view. Rather than searching for some common style among aging artists, we can ask instead whether there has been a systematic association between age and innovation. Study of this question has led us to believe that there 
have been two distinct life cycles among important artists, each of which has been associated with a different type of innovation. We can consequently begin by describing these types. What distinguishes the innovations is not their importance, for as will be seen below both types are represented among the major innovations in the history of art. What distinguishes them instead is the method by which they are produced. One of these methods is based on induction and can be called aesthetically-motivated experimentation, whereas the other is deductive, and can be called conceptual execution.

One way to define the key difference between the two methods is by modifying an analysis of the philosopher Richard Wollheim, who proposed that

the production of an art object consists, first of all, in a phase that might be called... "work" tout court: that is to say, the putting of paint on canvas, the hacking of stone, the welding of metal elements... But the second phase in artistic productivity consists in decision...: namely, the decision that the work has gone far enough. ${ }^{17}$

To Wollheim's two stages we add another, which occurs prior to his two. This consists of any preparations the artist makes before starting to put paint on canvas. Making a painting then has three stages - planning, working, and stopping.

For the experimental artist, the planning of a painting is of little or no importance. The motif is often selected for convenience, as in many cases the artist simply returns to a subject he or she has used in the past. The experimental painter rarely makes detailed plans or sketches before beginning a particular painting. Once a painting is begun, the working stage is openended. The artist makes a series of decisions during this stage based on visual inspection of the developing painting, changing things when he isn't satisfied with the appearance of the work. 
The decision to stop is also based on visual inspection: the painter stops when he is satisfied with the work's appearance, or abandons it as a failed effort. The decision to stop is typically a difficult one, for lacking a specific goal, the artist often has trouble deciding whether he has achieved enough in any individual work. And the decision is generally provisional, so experimental artists often return to work on a painting they had earlier considered finished, even after long intervals.

In contrast, for the conceptual artist the most important decisions are made in planning a work. Before beginning, the artist either envisions the completed work, or specifies a set of procedures that will be used to produce it. Conceptual artists often make detailed preparatory drawings or studies. The working stage involves executing the plan, either by producing the preconceived image, or carrying out the prescribed procedures. The artist stops when he has achieved the preconceived image, or has fully carried out the process he planned.

The experimental artist's approach is inductive: the artist proceeds by trial-and-error, judging trials as successes or failures based on their appearance. He considers progress to be achieved gradually as the cumulative effect of a series of incremental successes. The conceptual artist's approach is deductive, as working methods are designed to achieve a discrete goal that is specified precisely in advance. Progress is attained in discrete steps, and works are judged as successes when they communicate the artist's ideas or emotions.

\section{$\underline{\text { Age and Artistic Innovation }}$}

The long periods of trial and error often required for experimental innovations means that they tend to occur late in an artist's career. This tendency is reinforced by the fact that experimental innovations often depend on skills that are acquired slowly, involving the artist's 
craftsmanship in using materials. In contrast, conceptual innovations are arrived at suddenly, as the product of new ideas, and can occur at any age. Radical conceptual innovations are in fact most often made by young artists, who have not yet become accustomed to existing conventions and traditional methods, and are more likely to be able to perceive and appreciate extreme departures from these accepted ways of working.

These relationships have a parallel to the research of psychologists on when practitioners in a variety of academic disciplines and arts have produced their major contributions. Psychologists have found that chemists, mathematicians, theoretical physicists, and poets typically do their best work at younger ages than do astronomers, biologists, geologists, and novelists. ${ }^{18}$ One proposed explanation for these differences suggests that they are a function of the rates at which creative ideations can be produced and elaborated: it may be possible both to conceive new ideas and to develop them more rapidly in disciplines that deal with more abstract concepts. ${ }^{19}$ The inductive method followed by experimental artists appears to make their enterprise resemble that of the more concrete and empirical disciplines considered by the psychologists, while the deductive approach of the conceptual artists makes theirs resemble that of the more abstract and theoretical disciplines.

\section{$\underline{\text { Case Studies }}$}

The value of our typology in explaining artists' life cycles can potentially be demonstrated in two very different ways. One is to test its prediction concerning the relationship between age and artistic innovation for large numbers of artists, using systematic econometric

analysis. This process has been started elsewhere. ${ }^{20}$ A second approach is to examine the careers of individual artists, to see whether the life cycle that our typology predicts fits with the actual 
development of their art, and the timing of their major contributions. This is the method that will be used here.

The selection of the artists considered is dictated by their importance in the history of western art. They cannot simply be taken from any existing list of the most important western painters, because no such list has been created through systematic quantitative analysis. ${ }^{21}$ Although defining the canon of western art lies beyond the scope of this study, however, it is possible to select artists who are obviously central to that canon. The nine artists we have chosen to consider are among a small group whose contributions have been so influential that it would effectively be impossible to exclude them from any coherent narrative of the development of western art.

Examining the careers of artists who have lived during the past two centuries presents fewer difficulties than for artists working earlier, because we know so much more about the lives and working methods of modern artists. Comparable information is much scarcer for the premodern era. It is for this reason that our selection of artists begins in Florence during the Italian Renaissance. It is only then that artists began to emerge from the artisan traditions of the Middle Ages to become known as individuals, recognized for specific contributions to an evolving body of new art. We are also fortunate to have a remarkably detailed account of Italian artists working between the early $14^{\text {th }}$ century and the middle of the $16^{\text {th }}$ century, written by the artist Giorgio Vasari, who was a friend and disciple of Michelangelo. First published in 1550, Vasari's Lives of the Artists is the first modern history of art. ${ }^{22}$ In addition to providing biographical information about scores of artists, Vasari's deep understanding of the development of art from the $13^{\text {th }}$ century to his own day allowed him to identify the central innovations of the time, and to 
trace their influence.

$\underline{\text { Masaccio (1401-1429?) }}$

Masaccio (Maso di Ser Giovanni di Mone Cassai) was perhaps the first of the young geniuses who shaped the history of modern painting. Even though he died around the age of 28, Masaccio's innovations were widely recognized by his contemporaries and for generations after as founding achievements of the Italian Renaissance.

Masaccio's accomplishment was to blend three major elements into a radically new art. Two were borrowed from earlier innovators. The older of these was based on the discoveries of his great Florentine predecessor, Giotto, a century earlier, as Masaccio adopted the techniques Giotto had used to break away from the flat, static images of medieval art. Following Giotto, Masaccio used shading of light and dark, foreshortening of forms, and overlapping of figures to create an illusion of three-dimensionality. Masaccio then achieved even more convincing representations of depth by using the linear perspective developed by his friend Brunelleschi. Finally, to these borrowed techniques Masaccio added his own great innovation, by using a single, consistent source of light in his paintings. Later named “chiaroscuro," Masaccio's spotlight effect produced greater drama and visual excitement than the less highly focused illumination of Giotto.

In combination, Masaccio's blending of these elements achieved an unprecedented representational illusionism. Instead of the ideal or schematic images of medieval art, paintings could now be perceived as visual extensions of the viewer's own world. Masaccio's technique quickly spread: Vasari observed that his frescoes in the Brancacci Chapel in the church of Santa Maria del Carmine in Florence, painted circa 1427, became a mecca for "all those who have 
endeavored to learn the art of painting ... to grasp the precepts and rules demonstrated by Masaccio for the correct representation of figures..23

Little is known about Masaccio's training, but his early artistic maturity is no doubt a consequence of the intensive apprenticeship system that Italian artists followed, from the medieval workshop tradition. Yet workshop practices also tended to discourage innovation. That Masaccio could contribute so much to the history of Renaissance art despite his very early death is a result of the conceptual nature of his contribution. His accomplishment was an extraordinary intellectual feat that gave painters a new vantage point that would dominate western art for five centuries, until another young genius would overthrow it with a new conceptual system.

Michelangelo (1475-1564)

Michelangelo Buonarroti might be assumed to have been a conceptual artist in view of the fact that he made his greatest contributions in media - sculpture, fresco painting, and architecture - not ordinarily conducive to experimentalism. All three generally involve careful planning, including preparatory drawings, and extensive teamwork, and all are inherently resistant to changes in program during the process of creation. Yet it is a measure of Michelangelo's artistry that he managed to impose on each of these media the sensibility of an experimental artist.

One of the distinctive features of Michelangelo's career was his consistent difficulty in bringing works to completion. Even the projects he did complete were often realized only under extreme pressure from his clients, as in his famous conflicts with Pope Julius II over the completion of the Sistine Chapel ceiling frescoes. Many other projects were either left 
unfinished or delivered in severely truncated form, such as the project to create a tomb for Julius, which exists only as a small fragment of Michelangelo's intended product. Among the parts of that project that have been preserved are the famous "bound slaves," which have long fascinated art lovers for the way in which their bodies appear to emerge out of the unfinished block of stone.

Art historians have often attributed Michelangelo's problems of concluding to his habit of taking on expensive, labor-intensive, and massively scaled projects. Instead, however, they appear to have stemmed primarily from the fact that in the process of executing commissioned works Michelangelo consistently extended their scope far beyond his patrons' expectations, or desires. In the case of the Sistine Chapel, for example, the Pope simply wanted Michelangelo to paint the forms of the twelve Apostles between the clerestory windows, and expected the ceiling to be finished quickly in a decorative pattern. What Julius got was instead an entire painted ceiling, such as had never been seen before, which illustrated key scenes from Genesis, and which was not completed until long after Julius had run out of patience.

Michelangelo's habit of revising his projects in the course of their execution was a consequence of his experimental approach. For the Sistine Chapel he radically changed the scale and style of the imagery as he worked on the ceiling. When he began, fearing that he lacked the requisite skill as a painter, Michelangelo enlisted numerous assistants to help him. But after having seen their preliminary drawings for the ceiling Michelangelo dismissed them all. Vasari tells us that Michelangelo even did without the usual apprentices who ground the paint pigments, preferring to perform every aspect of the project himself. When the ceiling was finally opened to public inspection it caused a sensation, but Michelangelo was still not satisfied. Vasari reports that he wished to retouch the painting "in order to enrich and to heighten the visual impact," and 
that he was deterred only by the prospect of having to rebuild the elaborate scaffolding. ${ }^{24}$

Michelangelo's old-age style has long been celebrated by art historians. Yet it was not the product of a radical break from his earlier art, but rather of steadily evolving techniques and ambitions. Michelangelo's early work shows that he shared in the High Renaissance love of classical art, joining such artists as Raphael and Leonardo in the search for a harmonious ideal in the perfection of form, gesture, and composition. Yet from the beginning Michelangelo was willing to subordinate physical verisimilitude, as evidenced in such things as correct bodily proportion, to the larger visual effect of his work, often achieved by the use of oversized, muscular figures, contorted in space. As he aged his dramatic distortions grew more extreme. Late in life, in his fresco of the Last Judgment in the Sistine Chapel, finished in 1541 at the age of 66, and the even more radical murals completed nine years later for the Vatican's Pauline Chapel, Michelangelo created extraordinarily complex compositions of interwoven figures, whose physical forms obeyed no laws other than Michelangelo's pictorial conception. By the end of his life Michelangelo's manner had become so idiosyncratic, and so far from the tastes of his own time, that despite his unmatched reputation as an artist his last paintings were virtually ignored until the $20^{\text {th }}$ century. Only modern tastes formed by the rise of expressionist painting have made these works more acceptable to audiences. Yet like his inability to consider his works finished, and the persistent need to revise his projects in progress, the continual, restless evolution of Michelangelo's art throughout his life is the hallmark of an experimental artist. $\underline{\text { Raphael (1483-1520) }}$

Raphael (Raffaello Santi) is paradigmatic of the young genius. Although his life was cut short at the age of just 37, he had completed his most famous painting, The School of Athens, in 
the Vatican, almost a decade earlier, at 28. Raphael's rich, harmonious colors, his idealized faces, and the essential clarity of form and composition of his pictures led many to consider Raphael the paragon of artistic perfection for more than four centuries. The newly founded art academies in the 18th century held Raphael's art to embody a set of clearly definable rules that could be taught to any student desiring good technique and beautiful painting. Through these art academies Raphael's art continued to exert influence on painting into the early 20th century.

Raphael was admired by his contemporaries for the apparent ease with which he produced his paintings. He was credited with producing his paintings in a timely fashion, and with always satisfying his clients. Vasari implies that it was his efficiency as well as his art that made Raphael so popular with patrons.

Throughout his biography, Vasari depicts Raphael as an artist who easily and perfectly absorbed the styles of other artists. And indeed his earliest work so closely resembles in style that of his first teacher, Pietro Perugino, that Raphael's early paintings can barely be distinguished from his master's. Later Raphael was successively inspired by the work of Leonardo and Michelangelo. From Leonardo, Raphael learned the older artist's extraordinarily subtle chiaroscuro, his paintings' almost imperceptible gradations of form from dark to light. He also acquired from Leonardo the device of ordering his figure groups in a pyramidal structure, which gave their compositions an underlying stability and symmetry. Raphael, however, surpassed Leonardo in the compositional complexity of works like The School of Athens. This painting contains no less than fifty-two ancient Greek thinkers and scientists. Despite the large number of figures, and their wide variety in size, posture, and gesture, Raphael wove them into a visually interlocking group, so that the viewer perceives these philosophers as both individually 
attractive to the eye and intelligible and unified as a group. ${ }^{25}$

Raphael achieved these results through careful planning. His drawings were highly prized by collectors in his lifetime, and many have survived, providing a clear view of his working methods. ${ }^{26}$ Unlike earlier artists working in fresco, Raphael planned the placement of the figures in his compositions in advance. For The School of Athens, Raphael drew a full-scale preparatory cartoon that depicts the entire lower half of the painted composition. ${ }^{27}$ The only significant difference between the cartoon for The School of Athens and the painting as it was executed was the addition of the architecture surrounding the figures, which Raphael built around them.

Whereas Vasari praised his friend Michelangelo as a solitary genius, he chose to denigrate Michelangelo's rival by portraying Raphael as the director of a large group of artists. There is an internal consistency to Vasari's account, however, that reveals Raphael's organizational genius and business acumen. For example, Vasari speaks of Raphael's enormous team of draftsmen, which he employed throughout Italy, and who, Vasari asserts, provided Raphael with "good designs which he could use in his work." 28 Vasari notes that these artists often partially executed Raphael's paintings based on his initial designs. Vasari even credits Raphael with inventing a new product line, of engraved reproductions of his own paintings. Engraving had been uncommon in Italy prior to Raphael; his initiative made the medium commonplace. ${ }^{29}$ Such engravings became an enormously important medium through which Italian Renaissance art spread its influence across Europe.

Raphael was a paragon of the conceptual artist. He achieved his greatest art work at an early age. His working methods were ruled by careful planning through the use of preparatory 
drawings and cartoons. His designs and instructions were so clear that Vasari suggests that even important parts of a painting could be left to assistants. He had the ability to change his style significantly in response to the work of other artists, conceptually reorganizing their influence into a distinctively new art whose influence would prove to be one of the greatest in the history of western painting. $\underline{\text { Titian (c. 1485-1576) }}$

During his unusually long life, Titian (Tiziano Vecellio) was one of the most sought-after artists in Europe. Courted by emperors, kings, princes, and popes, Titian reached a social prominence that no artist had achieved before. Titian's career anticipates the great court artists of the $17^{\text {th }}$ century, painters such as Diego Velazquez, Peter Paul Rubens, Gianlorenzo Bernini, or Rubens' pupil Anthony van Dyck. Titian's example as a princely artist paralleled the influence his art exerted over painting for centuries after his death. ${ }^{30}$

Titian was an experimental artist. Although he was one of the most prolific painters of the $16^{\text {th }}$ century, few of his drawings are known. Since the drawings of many contemporaries have survived in considerable numbers, this indicates that Titian rarely considered it necessary to plan his paintings in advance, which had been the norm of Italian workshop practice. Titian learned this way of working from his slightly older colleague and rival, Giorgione. A witness described Titian's manner of painting: "He used to sketch in his pictures with a great mass of colors, which served, as one might say, as a bed or a base for the compositions... Having constructed these precious foundations he used to turn his pictures to the wall and leave them there without looking at them, sometimes for several months. When he wanted to apply his brush again he would examine them with the utmost rigor, as if they were his mortal enemies, to 
see if he could find any faults; and if he discovered anything that did not fully conform to his intentions he would treat his picture like a good surgeon would his patient ... [T]he final stage of his last retouching involved his moderating here and there the brightest highlights by rubbing them with his fingers, reducing the contrast ... and harmonizing one tone with another."’31

Titian inherited his experimental method from Giorgione, but far surpassed him in accomplishment. Titian succeeded in combining what had previously been the two great independent stylistic tendencies of Renaissance painting, as his art joined the color and luminous surfaces of such Flemish artists as Jan van Eyck with Raphael's complex and harmonious compositions. As he matured, Titian went beyond High Renaissance conventions by creating new, dynamic spatial relationships, in which the figures in his paintings would not uniformly face a single position in front of the canvas, but would be arranged in groups to imply several distinct viewing positions. This produced the effect of giving spectators differing perceptions of a single work as they walked toward it, and pointed toward later developments in western painting in which artists increasingly aimed to make viewers active participants in the experience of seeing their work. Interestingly, $\mathrm{x}$-ray analysis has revealed that Titian arrived at this innovation experimentally, reorienting the figures within a composition by a process of trial and error during the execution of individual works. ${ }^{32}$

Titian's manner changed greatly as he aged. Late in his life his paintings became more roughly worked and the surfaces of the canvases more thickly built up with paint. The visual clarity and precision of his early work gave way to a more atmospheric presentation, with features art historians have since categorized as "painterly," a style that emphasizes the worked surface of the painting, displaying rather than disguising the artist's touch. Vasari described 
Titian's evolution, and suggested its source in the development of his experimental method: whereas "the early works are executed with incredible delicacy and diligence, and they may be viewed either at a distance or close at hand; ... these last works are executed with bold, sweeping strokes, and in patches of color, with the result that they cannot be viewed from near by, but appear perfect at a distance... [I]t is clear that Titian has retouched his pictures, going over them with his colors several times.. ${ }^{33}$ In his late work Titian was considered to have pioneered a new approach to art, in which painting was no longer merely an imitation of the world, but an autonomous equivalent.

For three centuries Titian's name was identified with the art of color and the painterly performance. In contrast to the European academies, which came to espouse rigid absolute standards of aesthetic perfection enforced through a strict regimen for both artistic education and production, Titian's work presented an alternative model, of the individualistic artist who discovers his own method through the act of painting itself. This model of heightened autonomy became an inspiration to many later painters, just as Titian's glorious development in old age became a spur to art historians to ponder the sources of the old-age style. We can now recognize that both Titian's individualism and his brilliant late works are direct consequences of the experimental method by which he developed his signature style.

$\underline{\text { Rembrandt (1606-1669) }}$

Rembrandt van Rijn is one of the few artists whose name is nearly synonymous with art for those unfamiliar with the subject. His popular reputation may be traced to the fact that Rembrandt's art is fused with the popular perception of Rembrandt the artist. In the Rembrandt myth, the artist's genius compelled the painter to go against the tastes of his own time. As he 
aged, he fell into tragic isolation. We now know that Rembrandt was not isolated, that he had a school of imitators and admirers, and that for much of his life he was praised by his contemporaries as Holland's greatest painter. His famous loss of fortune during the second half of his life is now known to derive from his spending habits rather than from public neglect.

The artist's myth has its foundation in the way in which Rembrandt, especially through his self-portraits, seemed to place himself at the center of his art. Throughout all his work Rembrandt created the illusion of subjectivity for the people he painted, the sense that they possessed not merely an external appearance, but an interior self. His capacity to hint at the inner life of his subjects was unrivaled by any artist before him, and approached by few after. Complementing this psychological dimension of Rembrandt's art was his unprecedented realism, conveyed as much by his love of the quotidian as by his style of painting. He inspired many later generations of artists who followed the dictum that truth to nature is superior to imitating the traditions and conventions of past art.

Recent research has demonstrated convincingly that Rembrandt was an experimental painter. His draftsmanship is justifiably famed, but although hundreds of his drawings are known today, it is now recognized that few if any of these served as plans for later paintings. ${ }^{34}$ Like Titian, whom he admired and imitated, Rembrandt blocked out the schemes for his pictures directly onto the primed canvas, and x-rays of his paintings confirm that he made frequent and significant changes in his compositions as he worked on them. Some of his best known paintings appear to have remained undetermined even thematically until late in their production. His 1654 Bathsheba, for example, now in the Louvre, appears to have been initially simply a study of a female nude. The painting only acquired its final designation when, in what scholars generally 
agree to be the last element added to the picture, Rembrandt placed a letter in the woman's hand. ${ }^{35}$

Rembrandt's choice of subjects also reflects his experimental nature, as he frequently returned to familiar themes to create new variations. The most remarkable instance of this practice was one of his most striking innovations. He was the first western artist to paint himself more than a few times: his self-portraits, which number at least 40 paintings and more than 30 etchings produced over a period of forty years, constitute one of the earliest extended series of studies of a single subject in the history of art, and even today remain one of the most celebrated.

Rembrandt worked slowly and painstakingly, and had trouble parting with his works. As is often the case with experimental artists, he was notorious for his difficulties in completing commissions. In a famous incident, a commissioned work of his that was already hanging in the Amsterdam Town Hall was returned to Rembrandt's studio, where he resumed work on it. Substantially changed, the revised painting was never returned to its public position.

Rembrandt's contemporaries did favor his early work over that of his later years. But for subsequent generations Rembrandt's most significant work begins in the 1640s, when the artist was in his thirties, and gains in importance from then on. Both critical assessments are a consequence of Rembrandt's progressive departure from the dominant contemporary model of what constituted good craft in the art of painting. The most popular Dutch painters of the time produced works in what was known as a "smooth" style, marked by little or no surface texture and no visible evidence of the application of paint. As Rembrandt aged, the surfaces of his works became rougher and more uneven, departing more and more radically from the mirror-like surfaces of the smooth style. Yet is was precisely in this evolution that Rembrandt made one of 
his greatest innovations, for his construction of a surface marked by variation in both the roughness and the thickness of the paint, now believed to have been produced by the use of paints mixed to different viscosities, complemented his famous chiaroscuro in heightening the visual emphasis on the focal points of his works. ${ }^{36}$ The gradual development of this innovation, which contemporaries called Rembrandt's "rough" style, reveals the experimental process of trial and error that lay behind its creation, and explains why it is Rembrandt's later works, which embody this innovation in its most extreme form, that are most celebrated today.

\section{$\underline{\text { Paul Cézanne (1839-1906) }}$}

When this investigation reaches the nineteenth century, important new sources of evidence often become available. One of these is artists' own descriptions of their methods and goals. Paul Cézanne's letters provide an eloquent account of his progress as an experimental innovator. So for example in September, 1906, just six weeks before his death, he wrote to his son:

I must tell you that as a painter I am becoming more clear-sighted before nature, but that with me the realization of my sensations is always painful. I cannot attain the intensity that is unfolded before my senses. I have not the magnificent richness of coloring that animates nature. Here on the bank of the river the motifs multiply, the same subject seen from a different angle offers subject for study of the most powerful interest and so varied that I think I could occupy myself for months without changing place, by turning now more to the right, now more to the left. ${ }^{37}$

In this short passage Cézanne describes nearly all of the basic characteristics of the experimental innovator, including his visual motivation, the elusiveness of his vague but ambitious goal, the slowness of his progress toward it, the incremental and serial nature of his enterprise, his view of his work as research, and his frustration. 
The irony of Cézanne's frustration at this late date stems from the fact that in time not only would he come to be recognized as the most important painter of his era, but that it would be his latest works that would be judged his greatest contribution. This is witnessed by the market value of that work. For many modern painters, including Cézanne, enough of their paintings have been auctioned in recent decades to allow econometric estimation of age-price profiles, which express the value of their paintings as a function of the artist's age at the time of their execution. ${ }^{38}$ Recent research has furthermore shown that the peaks of these age-price profiles generally correspond closely to the judgments of art experts as to when the artists produced their most important work. ${ }^{39}$ For Cézanne, Figure 1 shows a steep rise in value during the early decades, with a plateau in mid-career, followed by a final increase in the last decade of his life. With a painting from age 25 worth only one-seventh as much as one from 65 , Figure 1 shows the relative unimportance of Cézanne's early, romantic works. The profile's first inflection point marks the beginning of Cézanne's artistic maturity. At 33, Cézanne moved to Pontoise, near Paris, where he spent the next few years learning the discoveries of Impressionism from Camille Pissarro, one of the movement's founders. Cézanne soon adopted several of the key innovations of the Impressionists, including the small brushstrokes, the bright palette, and the use of color instead of shading to achieve the illusion of depth.

Yet although he would ever thereafter share the Impressionists' devotion to paining nature, Cézanne rejected their goal of portraying the momentary effects of light and atmosphere, His apprenticeship to Pissarro allowed him to formulate his own goal, that would occupy the rest of his career, of making Impressionism more solid and timeless. His most radical achievements in this quest, which included his use of multiple viewpoints within a single picture and his 
trademark constructive brushstroke that simultaneously creates a two-dimensional surface pattern and tilts back into three-dimensional space, became seminal discoveries. These innovations appeared most clearly in his latest works, which influenced almost every significant artistic development of the next generation, including movements as diverse as the Cubists, who saw in Cézanne's brushstrokes a series of planes that could define three-dimensional space, and the Fauves, who seized instead on the surface pattern created by the colors of those brushstrokes.

Cézanne worked by trial and error. As a result, as critic Clive Bell observed, for Cézanne "every picture was a means... something he was ready to discard as soon as it had served his purpose. He had no use for his own pictures. To him they were experiments. He tossed them into bushes, or left them in the open fields. ${ }^{40}$ His primary goal was not to create images, but to learn. A fellow painter who once worked with him reported that Cézanne "never ceased declaring that he was not making pictures, but that he was searching for a technique." ${ }^{41}$ As an experimental painter, Cézanne was acutely aware of the difficulty of reaching a definitive conclusion: near the end of his life he wrote to a younger painter that "I progress very slowly ... and the progress needed is endless. ${ }^{, 42}$ But that he was in fact making progress is witnessed by the vast influence of his last works.

\section{$\underline{\text { Pablo Picasso (1881-1973) }}$}

In contrast to Cézanne, who told Maurice Denis "I seek in painting," the dominant artist of the next generation, Pablo Picasso, declared "I don't seek, I find." ${ }^{43}$ If there is little question that Cézanne was the most important experimental innovator in French modern painting, there is even less that Picasso was the most important conceptual innovator, and the greatest young genius in the history of modern art. ${ }^{44}$ 
The ambitious young Spaniard arrived in Paris to settle in 1904. Recognizing that he would have to produce a major work to challenge Henri Matisse for the leadership of the city's advanced art world, late in 1906 Picasso began planning the largest painting he had ever attempted. For months he filled sketchbooks with preparatory drawings. Historian William Rubin has estimated that in all Picasso made between four and five hundred studies for the painting, "a quantity of preparatory work unique not only in Picasso's career, but without parallel, for a single picture, in the entire history of art." ${ }^{\prime 4}$ At the age of 25, Picasso thus deliberately set out to produce a masterpiece. Remarkably, he succeeded, as that work became the single most celebrated painting in the history of modern art. $^{46}$

Completed in 1907, Les Demoiselles d'Avignon combined influences as diverse as preRoman Iberian sculpture, African carvings, and the late style of Cézanne to announce the origins of Cubism, "perhaps the most important and certainly the most complete and radical artistic revolution since the Renaissance." ${ }^{47}$ From that point of departure, Picasso collaborated closely with Georges Braque to produce a series of innovations. Their goal was to represent the tangible nature of objects without the use of linear perspective, which they considered a mistaken convention, and without the Impressionists' use of color, which they believed revealed only a momentary reflection of light rather than a durable underlying reality. They based one of their most striking early developments on the late Cézanne's use of several vantage points in a single composition. Picasso and Braque extended this approach, as the faceting that gave rise to the (initially pejorative) name of Cubism allowed them to portray objects simultaneously from many viewpoints, showing features of the objects that an observer knows are present even when they are temporarily hidden from view. Another in the series of new developments occurred in 1912, 
when Picasso made the first collage, Still Life with Chair Caning. In this he broke with a basic tradition of western painting by attaching a material object to the surface of the work. In violating the two-dimensionality of the picture surface plane, and doing this with a discarded scrap of cloth, Picasso challenged the traditional aesthetic purity of painting as a fine art, and initiated a process in which the boundary between painting and other artistic media would increasingly be broken down.

Picasso would go on to paint for more than six decades after producing the Demoiselles. During his long and enormously productive career, he would become by far the most celebrated artist of the twentieth century. Yet he would never produce another painting as important as the Demoiselles, or create another body of work as significant as that he executed between 1907 and the outbreak of World War I, when Braque's service in the French army effectively ended the two artists' joint research in Cubism. Figure 2 shows that the value of Picasso's work peaked at age 26, the year he painted the Demoiselles, and declined steadily thereafter. That the greatest work of the greatest artist of the twentieth century was done at such an early age is a consequence of the conceptual nature of Picasso's approach. Thus as historian John Golding recognized,

the Cubism of Picasso and Braque was to be essentially conceptual. Even in the initial stages of the movement, when the painters still relied to a large extent on visual models, their paintings are not so much records of the sensory appearance of their subjects, as expressions in pictorial terms of their idea or knowledge of them. "I paint objects as I think them, not as I see them," Picasso said. ${ }^{48}$

$\underline{\text { Jackson Pollock (1912-1956) }}$

Jackson Pollock was recognized as the leading member of the Abstract Expressionist movement even during his lifetime, and this perception has become stronger since his death in an 
automobile accident in 1956. Although the Abstract Expressionists were generally considered to be a group, by themselves as well as others, they did not share a common style. They were unified chiefly by their dissatisfaction with existing methods of painting, and by their desire to draw on the subconscious to create new forms of art. Many in the group also consciously wanted to depart from European art. Thus when an interviewer asked Pollock in 1943 whether he wanted to go abroad, he replied bluntly, "No. I don't see why the problems of modern painting can't be solved here as well as elsewhere."49

The Abstract Expressionists shifted the center of the art world from Paris to New York. They attracted attention for their revolutionary working methods as well as for their dramatic new images. And it was Pollock who developed both the most celebrated technique and the most startling results. His signature drip method of applying paint, with the inevitable puddling and spattering that could not be completely controlled by the artist, was developed specifically in order to avoid preconception. In a frequently quoted statement, Pollock declared that

When I am in my painting, I'm not aware of what I'm doing. It is only after a sort of "get acquainted" period that I see what I have been about. I have no fears about making changes, destroying the image, etc., because the painting has a life of its own. I try to let it come through. ${ }^{50}$

For Pollock, producing a painting was a visual process. After a period of applying paint, he would study the work to see how he should continue. This required a considerable effort, because he worked on large canvases laid flat on the floor. His widow, Lee Krasner, recalled their procedure:

How well I remember when Pollock would want to study one of those big canvases up on the wall. He'd attach the top edge to a long piece of $2 \times 4$, and together we'd lift it up - do you know how 
much one of those big pictures with all that paint weighed? We'd take it to the wall, and lift it up ladders, and just nail the ends of the $2 \times 4$ - which stuck out - into the studio wall. ${ }^{51}$

This process would be repeated a number of times, over a period of days or weeks, until Pollock felt the work was finished. Even then he often remained unsure, as Krasner recalled that "he'd have last-minute thoughts and doubts. He hated signing. There's something so final about a signature." ${ }^{52}$ And Krasner remembered that the extremity of the departure of Abstract Expressionism often produced even deeper doubts: "in front of a very good painting... he asked me, 'Is this a painting?' Not is this a good painting, or a bad one, but a painting!"’53

Abstract Expressionism departed from the goal of representing objects external to the artist, and made the work of art not only a representation of the artist's emotions, but a visible record of the process of its own creation. For centuries, a central objective of much of western art had been to make works that hid the evidence of the process by which the work was made. Since the mid-nineteenth century, one tendency of modern art had been to leave traces of the creative process in the finished work, in the form of visible brushstrokes, bare patches of canvases, and other devices. Abstract Expressionism carried this tendency further, by effectively making the process of creation the subject of the work, with the artist's gestures featured in the final product. And the Abstract Expressionists arrived at this result experimentally, with the work of each artist developing gradually over long periods.

Pollock made a number of specific innovations that proved influential. His technique of dripping paint on canvases laid on the floor offered a clear alternative to the traditional use of brushes and easels. His use of wall-sized canvases offered a new scale for paintings, and his allover compositions, that had no central focal point of interest, offered new visual effects. Beyond 
these technical contributions, however, lay Pollock's conviction that “I paint it, I don't illustrate it," as his work inspired many artists to use paint and other materials not to create representations of objects or ideas, but instead as the record of gestures and motions. ${ }^{54}$

Figure 3 shows that Pollock's work rose in value with age throughout most of the two decades of his career. During this time his work evolved by trial and error through a series of stages, from clumsy landscapes heavily influenced by Albert Pinkham Ryder and Pollock's teacher, Thomas Hart Benton, to Surrealist-inspired works derived from Joan Miró and Picasso, and then to the mature works in his signature style. There is a strong critical consensus that his greatest work was done during 1947-50, which is consistent with the peak his age-price profile reaches for paintings from 1950.

$\underline{\text { Jasper Johns (1930- ) }}$

Jasper Johns was a young genius in a generation of modern art dominated by them. During the late 1950s and “60s, Johns, Roy Lichtenstein (1923-97), Robert Rauschenberg (1925- ), Andy Warhol (1928-87), Sol LeWitt (1928-), Frank Stella (1936- ), and others created a series of new movements. In spite of their diversity, these movements shared a common basis in rejecting the methods of Abstract Expressionism and replacing them with conceptual approaches. Among the artists of that cohort, Johns is often considered to have been the key transitional figure in the shift from gesture painting to more mechanistic forms of art.

Johns entered the consciousness of the New York art world in dramatic fashion in January, 1958, when he had his first one-man show at the gallery of Leo Castelli. The show attracted great publicity; even before it opened Thomas Hess, the editor of Artnews, had borrowed one of the paintings and placed it on the front of his January issue, putting Johns in the 
unique position of having his debut announced on the cover of a leading art magazine. The impact of the show stemmed from Johns' radical departure from gestural abstraction: although they used a painterly surface taken from Abstract Expressionism, the paintings in his show presented flat depictions of two-dimensional objects - targets, numerals, and flags. The influence of these images on young artists who were looking for alternatives to Abstract Expressionism was almost immediate. So for example Frank Stella, then a college senior, saw the show and was struck by Johns' repetitive use of the stripes of the flags. ${ }^{55}$ Just two years later Stella would have his own first show, also at Castelli's gallery, with paintings that consisted solely of black stripes on white surfaces. Through this development by Stella, Johns' early work later led to the radical simplifications of Minimal and Conceptual art. By a very different process, Johns' portrayals of everyday objects would also contribute to the flat representational images of Pop Art. Johns' work thus became celebrated as a crucial link between the dominant art of the 1950s, Abstract Expressionism, and the new art of the "60s and beyond, beginning with Minimalism and Pop.

The example of Johns' approach to art also helped to transform modern painting from an experimental to a conceptual enterprise. Unlike the Abstract Expressionists' journeys into the unknown, the images in Johns' paintings were preconceived: when asked why he painted flags and targets, he replied that it was because they were "preformed, conventional, depersonalized, factual, exterior elements. ${ }^{156}$ In contrast to the drama that surrounded the production of Abstract Expressionist paintings, Johns confessed that "often I'm bored" while working. ${ }^{57}$ And Johns' avowed goal was to avoid autobiography: "I didn’t want my work to be an exposure of my feelings. ${ }^{158}$

Now past the age of 70, Johns is widely considered one of the most important painters 
alive, and all of his work is eagerly sought by collectors and museums. But his most celebrated work remains that he did early in his career. Figure 4 shows that this work is also his most valuable, as the peak of his age-price profile is for the paintings he executed immediately before his first show at Castelli's gallery. As would be the case for Stella and many of the other major artists of his generation, the work that introduced Johns to the art world was thus that which would remain his most significant. ${ }^{59}$ This is an obvious consequence of the conceptual nature of these artists' contributions, as the radical new ideas of the young geniuses of the late ' $50 \mathrm{~s}$ and '60s replaced the expressive gestures of the Abstract Expressionists as the driving force of the modern art world.

\section{Quantifying Artistic Success}

Systematic evidence on the differing careers of the artists considered here can be drawn from textbooks of art history. Authors choose the illustrations in these books in order to show readers what they consider each artist's most important contribution, or contributions. Analyzing the illustrations in a number of textbooks can consequently offer a survey of art historians' opinions on when an artist produced his best work. ${ }^{60}$

Table 1 clearly demonstrates the difference in the timing of the careers of the two types of innovators. Whereas the four conceptual innovators were all in their $20 \mathrm{~s}$ in the single year of their careers that the 15 textbooks surveyed here deemed their most important, the five experimental innovators were all over 35 in the single year of their careers that yielded the most illustrations. Cézanne was 67 when he did the work most often reproduced in the textbooks, more than 40 years older than Picasso when he did his most often illustrated work. The full age distributions of each artist's illustrations tell a similar story, as the median illustrations of the 
Table 1: Survey of Illustrations in 15 Textbooks

\begin{tabular}{|l|l|c|c|}
\hline Artist & $\mathrm{n}$ & $\begin{array}{c}\text { Artist's age in year of } \\
\text { median illustration }\end{array}$ & $\begin{array}{c}\text { Age in single year with most } \\
\text { illustrations }\end{array}$ \\
\hline \hline Masaccio & 35 & 26 & 24 \\
\hline Raphael & 52 & 28 & 28 \\
\hline Picasso & 88 & 31 & 26 \\
\hline Johns & 13 & 26 & 25 \\
\hline & & & \\
\hline Michelangelo & 123 & 40 & 37 \\
\hline Titian & 52 & 53 & 41,53 \\
\hline Rembrandt & 69 & 46 & 36 \\
\hline Cézanne & 36 & 56 & 67 \\
\hline Pollock & 17 & 38 & 38 \\
\hline
\end{tabular}

Note: $\mathrm{n}$ is the total number of illustrations of each artist's work in the books surveyed.

Sources:

Laurie Schneider Adams, A History of Western Art (New York: Harry N. Abrams, 1991).

Ralph A. Britsch and Todd Britsch, The Arts in Western Culture (Englewood Cliffs, NJ: Prentice-Hall, 1984).

Dale G. Cleaver, Art, Second edition (New York: Harcourt Brace Jovanovich, 1972).

Sara Cornell, Art (Englewood Cliffs, NJ: Prentice-Hall, 1983).

Horst de la Croix and Richard G. Tansey, Gardner's Art Through the Ages, Sixth edition (New York: Harcourt Brace Jovanovich, 1975).

Julian Freeman, Art (New York: Watson-Guptill Publications, 1998).

Volker Gebhardt, The History of Art (New York: Barron’s, 1998).

Fredrick Hartt, Art, Third edition (Englewood Cliffs, NJ: Prentice-Hall, 1989). 
Hugh Honour and John Fleming, The Visual Arts, Fifth edition (New York: Harry N. Abrams, 1999).

Martin Kemp, editor, The Oxford History of Western Art (Oxford: Oxford University Press, 2000).

Ariane Ruskin, History in Art (New York: Franklin Watts, 1974).

Harold Spencer, The Image Maker (New York: Charles Scribner's Sons, 1975).

Marilyn Stokstad, Art History (New York: Harry N. Abrams, 1995).

David G. Wilkins, Bernard Schultz, and Katheryn M. Linduff, Art Present (New York: Harry N. Abrams, 1997).

Michael Wood, Bruce Cole, and Adelheid Gealt, Art of the Western World, (New York: Simon and Schuster, 1989). 
four conceptual artists were of work done at ages ranging from just 26 to 31 , well below the comparable range for the five experimental artists, from 38 to 56.

Analysis of the textbooks provides quantitative confirmation for a qualitative judgment that would occasion little debate among art historians, for there is a broad consensus among experts that Masaccio, Raphael, Picasso, and Johns made their major contributions early, and that Michelangelo, Titian, Rembrandt, Cézanne, and Pollock produced their greatest work later in their careers.

\section{Conclusion}

When the distinguished English art critic Roger Fry was elected to a professorship of art history at Cambridge University in 1933, a central theme of his inaugural lecture was an appeal to make the study of art history more systematic. In proposing the elements of an analytical framework, Fry observed that an artist's age inevitably influenced his work. In a remarkable passage, he proposed a dichotomy:

When we look at the late works of Titian or Rembrandt we cannot help feeling the pressure of a massive and rich experience which leaks out, as it were, through the ostensible image presented to us, whatever it may be. There are artists, and perhaps Titian and Rembrandt are good examples, who seem to require a very long period of activity before this unconscious element finds its way completely through into the work of art. In other cases, particularly in artists whose gift lies in a lyrical direction, the exaltation and passion of youth transmits itself directly into everything they touch, and then sometimes, when this flame dies down, their work becomes relatively cold and uninspired.

Fry acknowledged that these comments must appear "rather wildly speculative and hazardous" to his audience. ${ }^{61}$ Yet we believe that we have now devised a systematic approach that has led us to a typology much like the one Fry proposed. For in our view Titian and Rembrandt are 
prototypical examples of artists whose experimental approach to their work did result in an art that matured slowly, in contrast to such artists as Raphael and Picasso, whose conceptual approach led them to make their greatest contributions quickly and very early in life.

It is perhaps unsurprising that art historians have not responded more successfully to Fry's challenge to understand artists' life cycles, because in general art historians have largely ignored Fry's appeal for more systematic approaches to their subject. In view of the extraordinary productivity of artists, it is perhaps more remarkable that economists have not taken more interest in their careers. But this too is perhaps not surprising, in view of the fact that economists have taken little systematic interest in understanding the considerable differences in the life cycles of experimental and conceptual innovators even in their own discipline. ${ }^{62}$ 


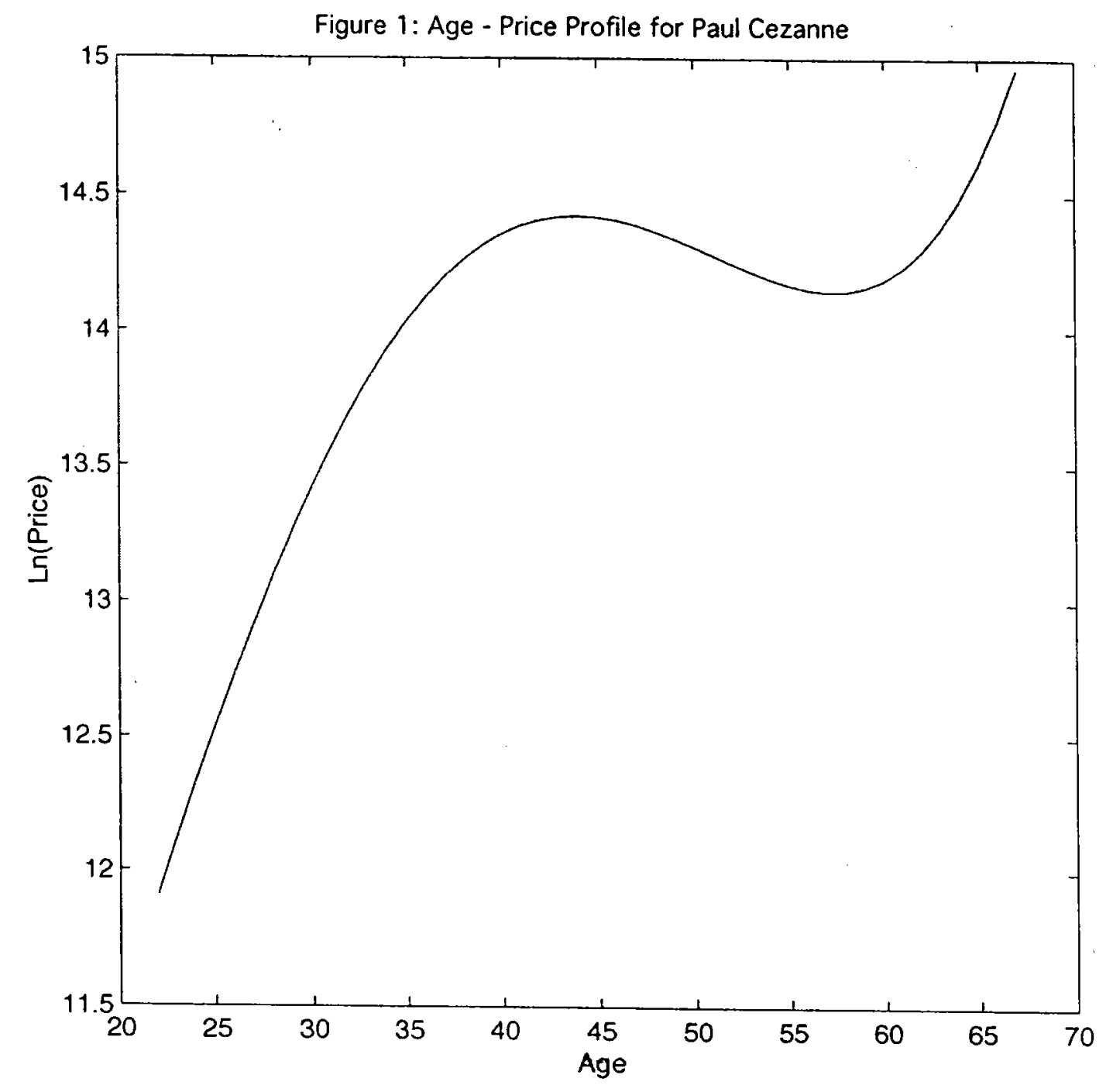


Figure 2: Age - Price Profile for Pablo Picasso

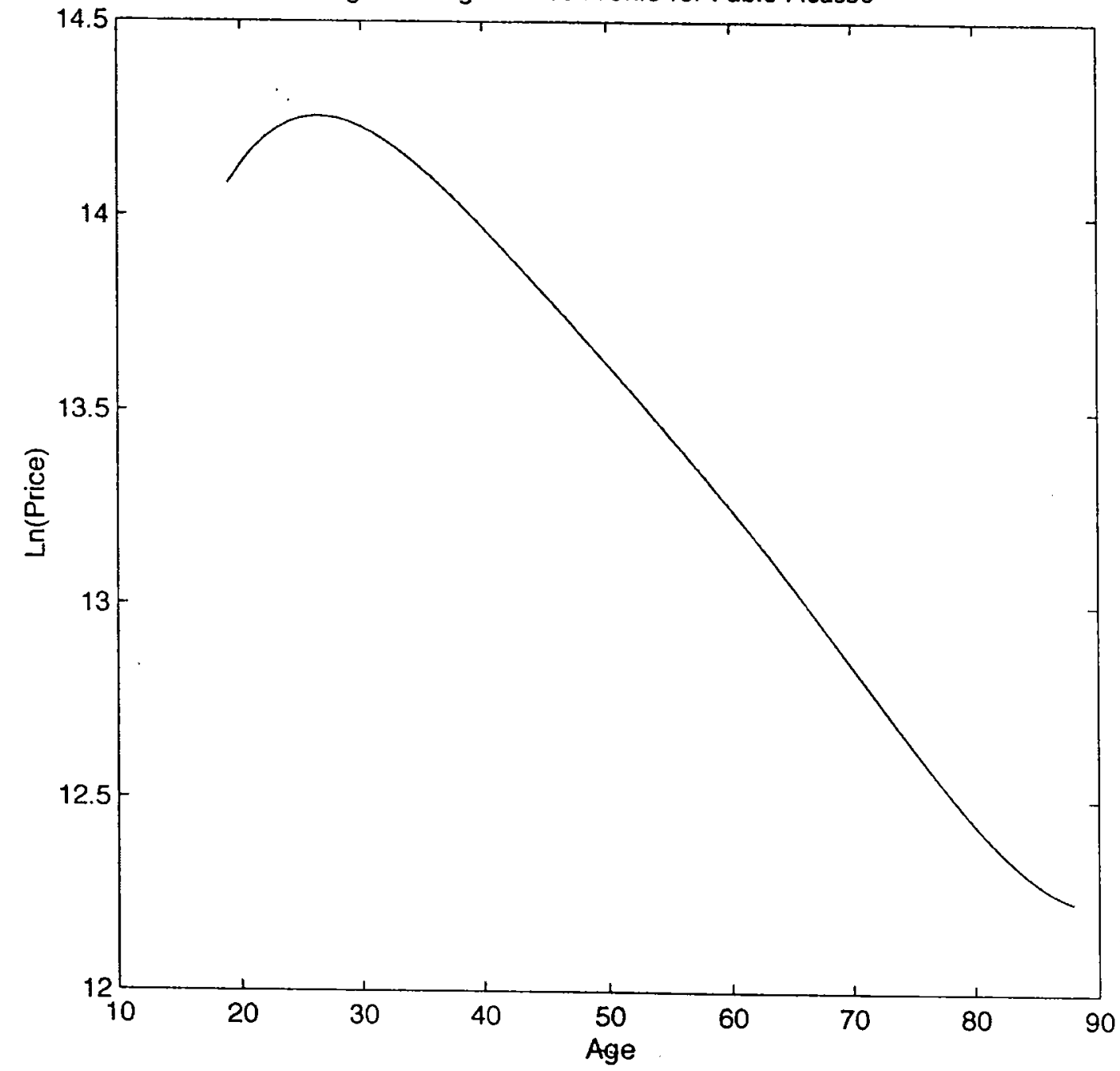


Figure 3: Age - Price Profile for Jackson Pollock

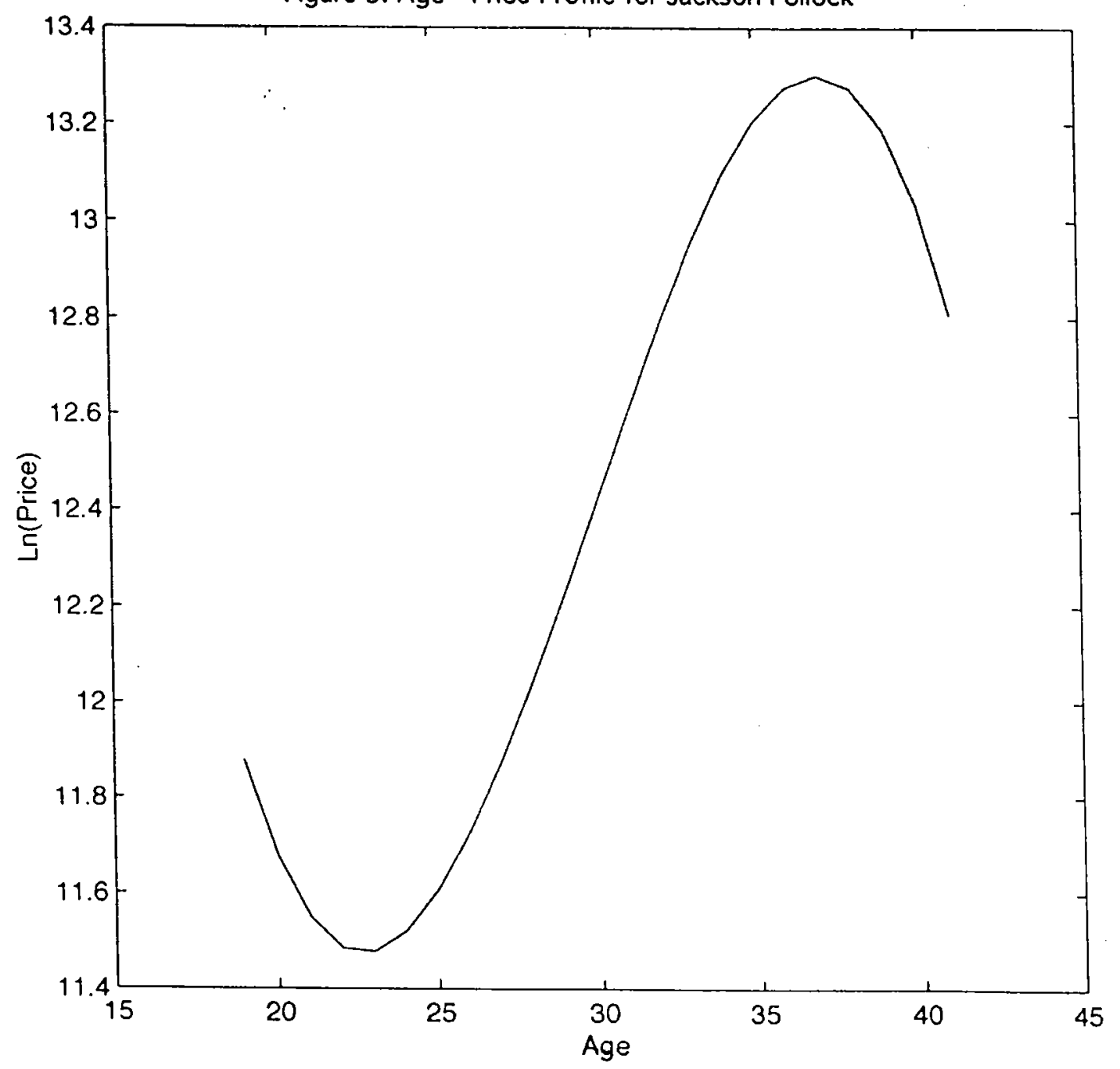




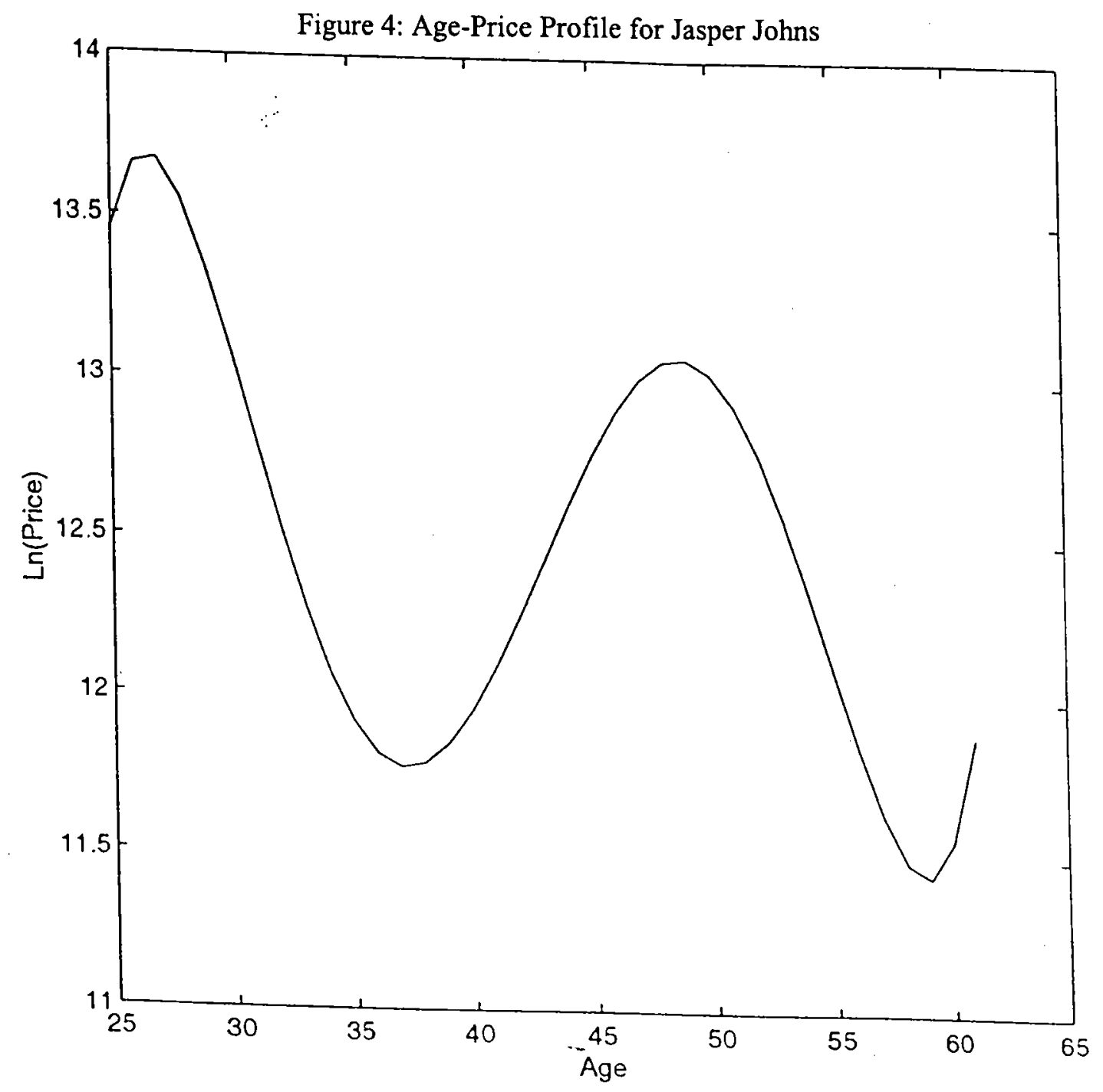




\section{$\underline{\text { Footnotes }}$}

We thank Emmet Larkin and participants in a seminar at the University of Chicago for comments, Thomas Walker for research assistance, and the National Science Foundation for financial support.

1. Meyer Schapiro, Modern Art: $19^{\text {th }}$ and $20^{\text {th }}$ Centuries (New York: George Braziller, 1979), p. 224.

2. Godfrey Barker, “The Art Market's Two-Ton Gorilla," Forbes, Volume 166, No. 16 (December 25, 2000), p. 146.

3. E.g. see Bruno S. Frey, "Superstar Museums: An Economic Analysis," Journal of Cultural Economics, Volume 22 (1998), pp. 113-25.

4. On the importance of these works, see David W. Galenson, "Quantifying Artistic Success: Ranking French Painters - and Paintings - from Impressionism to Cubism," Historical Methods (forthcoming), Table 3.

5. Studies of price determination include Bruno S. Frey and Werner W. Pommerehne, Muses and Markets (Oxford: Basil Blackwell, 1989), and Madeleine de la Barre, Sophie Docclo, and Victor Ginsburgh, "Returns of Impressionist, Modern and Contemporary European Paintings, 1962-1991," Annales d'Economie et de Statistique, No. 35 (1994), pp. 143-81.

6. James Albert McNeill Whistler, The Gentle Art of Making Enemies (New York: G. P. Putnam's Sons, 1922), p. 5.

7. Vincent van Gogh, The Complete Letters of Vincent van Gogh (London: Thames and Hudson, 1958), Volume 3, pp. 399-400.

8. Robert Jensen, Marketing Modernism in Fin-de-Siècle Europe (Princeton: Princeton University Press, 1994), pp. 112, 303.

9. David Rosand, "Editor's Statement: Style and the Aging Artist," Art Journal, Volume 46, No. 2 (Summer 1987), p. 91.

10. Meyer Schapiro, Impressionism: Reflections and Perceptions (New York: George Braziller, 1997), p. 180.

11. In recognition of this problem, after examining the contributions of the four papers contributed to the 1985 symposium, the discussant for that session closed his remarks by urging that "what now ought to be done is an investigation to see at what age the majority of these [important] artists produced their major or most significant works, and in how many the creative vigor - whatever form it took - continued unabated, or declined, and if 
so, when;" Julius S. Held. "Commentary," Art Journal, Volume 46, No. 2 (Summer 1987), p. 133. The present paper can be considered as a partial response to Held's appeal.

12. Schapiro, Modern Art, p. 152.

13. George Kubler, The Shape of Time: Remarks on the History of Things (New Haven: Yale University Press, 1962), p. 33.

14. For a recent statement of this view see David Gelernter, "Paradoxes of Painting," Commentary, Vol. 111, No. 4 (April 2001), pp. 38-39)

15. Arthur Koestler, The Act of Creation (New York: Macmillan, 1964), pp. 393-94.

16. Alan Bowness, The Conditions of Success: How the Modern Artist Rises to Fame (New York: Thames and Hudson, 1989), pp. 9, 11.

17. Richard Wollheim, "Minimal Art," in Gregory Battcok, ed., Minimal Art: A Critical Anthology (Berkeley: University of California Press, 1995), p. 396.

18. Harvey C. Lehman, Age and Achievement (Princeton: Princeton University Press, 1953), pp. 324-25; Dean Keith Simonton, Scientific Genius: A Psychology of Science (Cambridge: Cambridge University Press, 1988), p. 67. Simonton, Greatness: Who Makes History and Why (New York: Guilford Press, 1994), pp. 185-88.

19. Simonton, Scientific Genius, pp. 68-75.

20. David W. Galenson, Painting Outside the Lines: Patterns of Creativity in Modern Art (Cambridge: Harvard University Press, 2001); Galenson and Bruce A. Weinberg, "Age and the Quality of Work: The Case of Modern American Painters," Journal of Political Economy, Vol. 108, No. 4 (August 2000), pp. 761-77; Galenson and Weinberg, "Creating Modern Art: The Changing Careers of Painters in France from Impressionism to Cubism," American Economic Review, forthcoming.

21. We believe that this can be done in future, however. For a demonstration of method, see Galenson, "Quantifying Artistic Success," and Martin Bruegel and David W. Galenson, "Measuring Masters and Masterpieces: French Rankings of French Painters and Paintings from Realism to Surrealism," (unpublished paper, University of Chicago, 2001), Table 2.

22. References in this paper are to a translation of the second edition; Giorgio Vasari, The Lives of the Artists (Harmondsworth: Penguin, 1971).

23. Ibid., p. 131.

24. Ibid., pp. 252-53. 
25. For discussion of Raphael's compositional innovations see Janis Bell, "Color and Chiaroscure," in Marcia Hall, ed., Raphael's "School of Athens" (Cambridge: Cambridge University Press, 1997), pp. 85-113.

26. Francis Ames-Lewis, The Draftsman Raphael (New Haven: Yale University Press, 1986).

27. Konrad Oberhuber and Lamberto Vitali, Il cartone per la "Scuola d'Athene" (Milan: Silvana Editoriale de'Arte, 1972).

28. Vasari, Lives of the Artists, p. 310.

29. Ibid., pp. 306-07.

30. David Rosand, "Titian and the Critical Tradition," in Rosand, ed., Titian: His World and His Legacy (New York: Columbia University Press, 1982), pp. 1-39.

31. Susanna Biadene, ed., Titian: Prince of Painters (Washington, D.C.: National Gallery of Art, 1990), pp. 23-24.

32. Rosand, "Titian and Pictorial Space," in Biadene, Titian: Prince of Painters, p. 98.

33. Vasari, Lives of the Artists, p. 458.

34. Svetlana Alpers, Rembrandt's Enterprise (Chicago: University of Chicago Press, 1988), pp. 15-16, 70-71.

35. Ernst van de Wetering, "Rembrandt's Bathsheba: The Object and Its Transformations," in Ann Jensen Adams, ed., Rembrandt's "Bathsheba Reading King David's Letter" (Cambridge: Cambridge University Press, 1998), pp. 27-47.

36. Ernst van de Wetering, Rembrandt (Amsterdam: Amsterdam University Press, 1997), pp. $155-90$.

37. John Rewald, ed., Paul Cézanne Letters (New York: Da Capo Press, 1995), p. 327.

38. For details of specification and estimation, see Galenson, Painting Outside the Lines, Chapter 2.

39. E.g. see David W. Galenson, "The Careers of Modern Artists: Evidence from Auctions of Contemporary Art," Journal of Cultural Economics, Vol. 24, No. 2 (May 2000), pp. 9198; Galenson, Painting Outside the Lines, Appendixes 1 and 2. Prices have previously been used as a measure of quality in art. In her 1940 biography of Roger Fry, for example, Virginia Woolf described the widespread public criticism of Cézanne and other artists Fry presented at an exhibition in 1910, then observed that "Time has vindicated Roger Fry, if money is any test. Shares in Cézanne have risen immeasurably since 1910. That family, who ... accumulated works by Matisse must today be envied even by 
millionaires;" Woolf, Roger Fry: A Biography (San Diego: Harcourt Brace Jovanovich, 1976), p. 159.

40. Clive Bell, "The Debt to Cézanne," in Francis Frascina and Charles Harrison, eds., Modern Art and Modernism (New York: Harper and Row, 1982), p. 77.

41. William Rubin, ed., Cézanne: The Late Work (New York: Museum of Modern Art, 1977), p. 37.

42. Rewald, Paul Cézanne Letters, p. 302.

43. Richard Shiff, Cézanne and the End of Impressionism (Chicago: University of Chicago Press, 1984), p. 222; Marilyn McCully, ed., A Picasso Anthology (Princeton: Princeton University Press, 1982), p. 252.

44. E.g. see Galenson, "Quantifying Artistic Success,” Table 2; and Bruegel and Galenson, "Measuring Masters and Masterpieces," Table 2.

45. William Rubin, Hélène Seckel, and Judith Cousins, Les Demoiselles d'Avignon (New York: Museum of Modern Art, 1994), pp. 14, 119.

46. E.g. Galenson, "Quantifying Artistic Success,” Table 3; Bruegel and Galenson, "Measuring Masters and Masterpieces," Table 3.

47. John Golding, Cubism, Third edition (Cambridge: Harvard University Press, 1988), p. xiii.

48. Golding, Cubism, p. 51.

49. Pepe Karmel, ed., Jackson Pollock: Interviews, Articles, and Reviews (New York: Museum of Modern Art, 1999), p. 15.

50. B. H. Friedman, Jackson Pollock: Energy Made Visible (New York: Da Capo Press, 1995), p. 100.

51. E. A. Carmean and Eliza E. Rathbone, American Art at Mid-Century: The Subjects of the Artist (Washington: National Gallery of Art, 1978), pp. 133-35.

52. Karmel, Jackson Pollock, p. 38.

53. Karmel, Jackson Pollock, p. 37.

54. Carmean and Rathbone, American Art at Mid-Century, p. 151.

55. William S. Rubin, Frank Stella (New York: Museum of Modern Art, 1970), p. 12. 
56. Kirk Varnedoe, editor, Jasper Johns: Writings, Sketchbook Notes, Interviews (New York: Museum of Modern Art, 1996), p. 112.

57. Varnedoe, Jasper Johns, p. 199.

58. Varnedoe, Jasper Johns, p. 145.

59. For discussion see Galenson, Painting Outside the Lines, Chapter 7.

60. For further discussion of the value of this procedure, see Galenson, "Quantifying Artistic Success."

61. Roger Fry, Last Lectures (Boston: Beacon Press, 1962).

62. See David W. Galenson and Bruce A. Weinberg, "The Economics of Creativity," NSF Proposal, August, 2000. 